\title{
Mihin sukupuolihistoriaa tarvitaan kasvatus- ja aikuiskasvatustieteessä
}

\author{
$y$ \\ Kasvatus- ja koulutushistorialle oli pitkään tyypillistä \\ tyttöjen ja naisten näkymättömyys ja sukupuolen \\ sivuuttaaminen. Sukupuolinäkökulman ulottaminen \\ kasvatuksen historiantutkimukseen tekee tilaa \\ kasvatusilmiöiden uusille tulkinnoille.
}

TARKASTELEN PUHEENVUORONI ALUKSI lyhyesti historian näkökulman tarpeellisuutta kasvatus- ja aikuiskasvatustutkimuksessa. Etsin vastausta kysymykseen, mihin historiaa ylipäänsä tarvitaan. Sen jälkeen pohdin, mihin sukupuolihistoriaa tarvitaan kasvatusalan tutkimuskentällä.

Otsikkoa voisi purkaa vielä kolmannellakin tavalla eli kysyä erikseen mihin sukupuolentutkimusta kasvatus- ja aikuiskasvatustieteessä tarvitaan, mutta en käsittele sitä tässä puheenvuorossa. Sukupuolen analysoinnin tarvetta aikuiskasvatustieteen tutkimuksessa ovat peräänkuuluttaneet mm. Marjo Vuorikoski ja Hanna Ojala kymmenen vuoden takaisessa Aikuiskasvatuslehden artikkelissaan (Vuorikoski \& Ojala 2006).

Omille opiskelijoilleni olen perustellut historianäkökulman tärkeyttä ja merkitystä historiatietoisuuskäsitteen avulla. Tätä käsitettä on hyödynnetty viime vuosikymmeninä paljon juuri historian käyttöön, opettamiseen ja oppimiseen liittyen. Sillä tarkoite- taan yksilön tai yhteisön suhdetta historiaan ja tapaa ymmärtää menneisyyden, nykyisyyden ja tulevaisuuden välisiä yhteyksiä. (Ahonen 1998, 25.)

Kysymys on myös siitä, mitä menneisyydestä tehdyt erilaiset tulkinnat merkitsevät meille ja millaisia aineksia saamme oman todellisuuskäsityksemme arviointiin. Millaisiin historiakuviin itse kiinnitymme, miten niitä käytämme ja miten muut niitä käyttävät? Olemmeko tietoisia siitä, miten historiaa hyödynnetään erilaisiin tarkoitusperiin elokuvissa, kirjoissa tai mainoksissa - ja joskus myös tutkimuksissa?

Suomessa aihetta on viime vuosina tutkittu muun muassa vuosina 2008-2012 toteutetussa laajassa Historiatietoisuus Suomessa -tutkimusprojektissa. Siinä kysyttiin tuhansilta suomalaisilta, mitä he ajattelevat menneisyydestä ja selvitettiin, miten heidän käsityksensä menneisyydestä vaikuttavat nykypäivän ajatteluun ja asenteisiin tai tulevaisuuden odotuksiin. (Torsti 2012.) 
Kasvatus \& Aika -lehti osallistui historiatietoisuudesta käytyyn keskusteluun julkaisemalla vuonna 2011 teemanumeron (Löfström ym. 2011), jossa aihetta käsiteltiin monipuolisesti. Mukana oli muun muassa Johanna Oljemarkin artikkeli, jossa tutkittiin syrjäytymisuhanalaisten työpajaa käyvien nuorten historiatietoisuutta. Se, miten nuoret ajattelivat menneisyydestä, vaikutti myös heidän toimintaansa nykyhetkessä sekä heidän tulevaisuudenodotuksiinsa ja omiin vaikutusmahdollisuuksiinsa (Oljemark 2011).

Historiatietoisuus-käsite on auttanut itseäni ymmärtämään kollektiivisen muistin ja historiakuvien merkitystä myös vallan välineenä. Sen avulla voin ymmärtää myös sen, miksi oman menneisyyskäsitykseni (jatkuva) muuttuminen muuttaa samalla käsityksiäni nykypäivästä, kuten kasvatuksen ja koulutuksen tämän päivän ilmiöistä.

\section{SUKUPUOLINÄKÖKULMA \\ HISTORIANKIRJOITUKSEN OSAKSI}

Tutkin aikanaan väitöskirjassani kansakoulun jatkoopetusta, sen yhteiskunnallisia merkityksiä ja sisältöjä noin sadan vuoden aikaperspektiivillä (Jauhiainen 2002). Kysymys oli kutenkin koulumuodosta, jota ei enää ollut olemassa. Miksi siis tuhlasin aikaa moiseen? Perustelut löytyivät vähitellen, kun ymmärsin tutkimusaiheen ajallisen jatkumon ja menneisyyden diskurssien merkityksen nykypäivän kannalta.

Tutkiessani työväestön nuorille suunnattua jatkoopetusta minulle avautui mahdollisuus tarkastella yhteiskuntaluokan ja sukupuolen kytkeytymistä toisiinsa. Tämä teema avasi kuitenkin uusia kysymyksiä: miten sukupuolta tulisi analysoida?

Kasvatus- ja koulutushistorialle oli pitkään tyypillistä tyttöjen ja naisten näkymättömyys tai sukupuolen sivuuttaminen. History of Education -lehti on kasvatuksen historian johtava eurooppalainen tiedelehti, jossa julkaistiin vielä 1970-luvulla tyttöihin tai naisiin liittyviä artikkeleita harvakseltaan, korkeintaan pari artikkelia vuosikertaa kohden. 1980-luvun lopulta lähtien sukupuoli alkoi kuitenkin näkyä yhä enemmän lehden artikkeleissa. (Goodman \& Martin 2004.)

Hain omaan tutkimukseeni ja sen tulkintoihin aineksia historiatieteiden piirissä käydystä keskuste-

\section{SuKupuolen}

\section{N̈̈KÖKULMA MUUTTAA}

\section{HISTORIAN JUONEN.}

lusta, jossa otettiin kantaa erilliseen naishistoriaan puolesta ja vastaan. Tarkoittiko naishistoria siis sitä, että aikaisempaa mieskeskeistä historiaa tulisi "täydentää" naisnäkökulmalla kirjoittamalla naisille oma historia ja paikata näin menneisyyden aukkoja?

Omaan sukupuolihistorialliseen orientaationi vaikutti historiantutkija Irma Sulkusen sukupuolihistoriallinen tulkinta ja hänen argumentointinsa erillistä naishistoriaa vastaan. Sulkusen mukaan olennaisempaa, kuin käsitellä naisia omana kategorianaan ja rakentaa heille oma historia, oli katsoa sukupuolta laajemmin ja pyrkiä tavoittamaan tutkittavan aikakauden oma sukupuolijärjestelmä erityispiirteineen. Tämä tarkoitti siis pikemminkin koko historian uudelleen kirjoittamista kuin erillisen naishistorian kirjoittamista. Myös lukuisat muut historiantutkijat, kuten Anne Ollila (2001) ja Marjatta Rahikainen (2008) ovat puhuneet historian suuren kertomuksen purkamisesta ja historian uudelleen kirjoittamisesta. Sukupuolen näkökulma muuttaa historian juonen.

Myös jatko-opetuksen historia kertoi oman aikansa sukupuolijärjestelmästä. Jatko-opetuksesta käydyssä yhteiskunnallisessa keskustelussa määriteltiin "kriittistä ikäkautta" elävän varhaisnuorison tilaa ja paikkaa perheen, työelämän ja koulun muodostamassa kolmiossa. Sukupuolella oli keskeinen merkitys tämän kolmion rakentumisessa. Hieman yksinkertaistaen voisi sanoa, että työläispoikien kansalaiskelpoisuus merkitsi säännölliseen palkkatyöhön, ahkeraksi ja kurinalaiseksi ammattilaiseksi sosiaalistumista, kun taas tyttöjen kansalaiskelpoisuus sidottiin äitiyteen, perheenemännyyteen ja kodin hoitamiseen. (Jauhiainen 2002.)

Omaa väitöskirjaani kirjoittaessani havaitsin, että suomalaisessa historiantutkimuksessa oli tutkittu vähän alempien yhteiskuntaluokkien koulumuotoja. Tyttöjen tai naisten koulutukseen kohdistunut kiinnostus oli suuntautunut pikemminkin korkeamman asteen koulutukseen. Oppikoulua käyneiden 
tai yliopistokoulutuksen hankkineiden naisten koulutuspolut kertoivat samalla naisten koulutususkosta, emansipaatiosta tai keskiluokan naisille avautuneesta työelämästä. Korkeamman asteen koulutushistorian tutkimus liittyi siten suomalaisen yhteiskunnan suureen tarinaan, johon on sisältynyt myös koulutuksen myötä tapahtuvan sosiaalisen nousun ideaali. Tämä tarkoitti kuitenkin samalla sitä, että suurin osa naisista jäi tutkimuksen ulkopuolelle.

\section{UUDET TUTKIMUSKOHTEET JA TULKINNAT}

Kasvatushistorian tutkimuskohteet ovat kertoneet myös siitä, että menneisyyden kasvatuksesta ja koulutuksesta on helpompaa tavoittaa lainsäätäjien, viranomaisten ja kasvatusajattelijoiden ääni kuin kasvatettavien ja koulutettavien kokemukset (ks. Rahikainen 2008). Viimeisten vuosikymmenten aikana kasvatuksen historia on kuitenkin monipuolistunut tutkimuskohteiltaan, lähtökohdiltaan ja tulkinnoiltaan. Suurmiesten rinnalle ovat astuneet tavalliset ihmiset, marginaalissa olleet ryhmät ja vähemmistöt. Institutionaalisen lähtökohdan sijasta ilmiöitä on alettu katsoa matalalla katseella, kokijoiden näkökulmasta. Sukupuolitutkimus ja feministinen tutkimus ovat tuoneet mentaliteettihistorian ja arkipäivän historian ohella historiantutkimukseen uudenlaisia kysymyksenasetteluja, lähdeaineistoja ja tulkintoja.

Kiinnostus sukupuoleen näkyi myös History of Education -lehdessä, jossa alettiin julkaista sukupuoli- tai feminismiteemaisia erikoisnumeroita, kuten teemanumerot vuosina 1988, 1993 ja 2000. (Goodman \& Martin 2004; Watts 2005a; 2005b). Joyce Goodman ja Jane Martin katsoivat vuosituhannen vaihteessa julkaistussa feministisen tutkimuksen teemanumerossa, että sukupuolinäkökulma ja feministinen näkökulma näkyivät vahvasti kasvatuksen historian tutkimuskentällä. Sukupuolinäkökulma yhdistyi erityisesti poststrukturalistisiin ja postkolonialistisiin teorioihin.

Samoin tutkimuksissa oltiin kiinnostuneita feminiinisyyden ja maskuliinisuuden rakentumisen historiallisesta analysoinnista. Goodman ja Martin painottivat, että sukupuolinäkökulma kasvatuksen historian tutkimuksessa avasi mahdollisuudet kasvatusilmiöiden uudelleen tulkinnoille. Sensitiivisyys sukupuolen suhteen herkisti myös muiden erojen ja erontekojen havaitsemiselle. (Goodman \& Martin 2000, 383-384.)

\section{SUKUPUOLEN MÄÄRITTELY}

Kasvatushistorian tutkija Ruth Watts (2005) on todennut, että tärkeämpää kuin se, kuinka paljon naisia lukumäärällisesti nostetaan esiin tutkimuskohteina, on se, millä tavalla ymmärryksemme sukupuolesta ja sen merkityksestä vaikuttaa laajemmin ymmärrykseemme kasvatuksen tutkimuskentästä. Tyttöjen tai naisten koulutushistoriaa koskevissa tutkimuksissa ei läheskään aina ole kyse sukupuolta problematisoivasta tutkimuksesta. (Watts 2005, 226-227)

Marianne Liljeströmin (2004) mukaan suomalaisessa historiantutkimuksessa on elänyt ja elää edelleen rinnakkain kaksi lähtökohdiltaan erilaista tapaa ymmärtää sukupuoli. Sukupuoli voidaan ymmärtää ensinnäkin ontologisena perustana yksilöiden todellisuudelle. Tällöin tutkimus pyrkii dokumentoimaan naisten tai miesten kokemuksia. Toinen tapa nähdä sukupuoli on konstruktivistinen. Sukupuoli ymmärretään tällöin kulttuurisesti ja sosiaalisesti tuotettuna, jatkuvien diskursiivisten käytäntöjen ja neuvottelujen tuloksena. Tällöin tutkimus pyrkii esimerkiksi selvittämään millaista käsitystä sukupuolesta koulutuskäytänteet ovat tuottaneet. (Liljeström 2004, 147; ks. Vehkalahti ym. 2014, 4-5.)

Sukupuolihistoriaan on vaikuttanut sukupuolentutkimuksessa 2000-luvulla käyty keskustelu intersektionaalisuudesta. Tutkimuksessa tulisi siis huomioida sukupuolen ohella muut sosiaaliset kategoriat, kuten etnisyys, ikä, luokka ja seksuaalinen suuntautuminen ja tarkastella sukupuolisuutta muiden kategorioiden yhteisvaikutuksen kautta (Jokinen, Ahlbäck \& Kinnarinen 2012, 178).

Feministisen tutkimuksen anti liittyy myös metodologisesti tärkeään kysymykseen tiedosta ja tieteellisen tiedon rakentumisen mekanismeista. (Watts 2003; 2005, 226-227). Tämä tarkoittaa kasvatusta koskevan tiedon ja kasvatustieteen analysoimista sukupuolittuneena ilmiönä.

Havahduin itse jossakin vaiheessa huomaamaan, että suomalainen kasvatustieteen historiankirjoitus oli unohtanut lähes kokonaan ensimmäisen nais- 
väittelijänsä. Kun siis olen omassa tutkimuksessani Kaino Oksasesta (Jauhiainen 2012; 2014) nostanut esille mielestäni tärkeän naistoimijan - ensimmäisen suomalaisessa yliopistossa kasvatusopista väitelleen naisen - minua on kiinnostanut ennen kaikkea se, mistä hänen "unohtamisensa" kertoo. Miksi kerromme mielellämme kasvatushistoriaa suurten nimien kaanonin kautta - ja he ovat lähes poikkeuksetta miehiä? Miten ja miksi näennäisesti sukupuoleton ja neutraali kasvatustieteellinen tieto on sivuuttanut sukupuoleen ja valtaan liittyvät kysymykset?

\section{MIEHEYDEN HISTORIALLINEN TUTKIMUS}

Kasvatuksen historian kentälle on toivottu lisää mieheyttä ja maskuliinisuutta analysoivia tutkimuksia, joissa myös miestä analysoitaisiin sukupuolena. Valtaosa sukupuolta problematisoivasta historiantutkimuksesta on käsitellyt naisia. (Vehkalahti, Tuomaala-Sarpong \& Hakosalo 2014, 4; Watts 2003.) Arto Jokinen, Anders Ahlbäck ja Kirsi Kinnarinen (2012) ovat viitanneet miehiin ja poikiin yhteiskuntatieteellisen ja humanistisen tutkimuksen "näkymättömänä sukupuolena”. Tällä he tarkoittavat juuri sitä, että miehistä tehdään edelleen vähän sukupuolitietoista tutkimusta: mies ei sukupuolistu. (Jokinen, Ahlbäck \& Kinnarinen 2012, 171-172.)

Mieheyden historiallista tutkimusta on siis Suomessa tehty toistaiseksi verraten vähän. Opettajuutta koskevissa tutkimuksissa sukupuolinäkökulma on ollut harvinainen. Niinpä nostan tässä esiin yhden esimerkin mieheyttä analysoivasta 2000-luvun kasvatushistoriallisesta tutkimuksesta. Jukka Kujala väitteli vuonna 2008 miesopettajuutta käsittelevällä väitöskirjallaan Miesopettaja itsenäisyyden ajan Suomessa elokuvan ja omaelämäkerran mukaan. Kujala etsi aineistoistaan miesopettajuuden kuvausta ja malliopettajuuden yhteiskunnallista muutosta. Kujalan aineisto edusti samalla uusia lähdeaineistoja, sillä hän käytti lähteinään miesopettajia kuvaavia elokuvia ja opettajien omaelämäkerrallista muisteluaineistoa. Esimerkiksi elokuvia hän analysoi valmistusajankohtansa tuotteina jotka kertoivat oman aikansa arvoista, yhteiskunnasta ja käsityksistä tuottamalla tietynlaista totuutta kuvaamistaan ilmiöistä.
Mieheyden historiaan liittyen Ilana Aalto on tutkinut mielenkiintoisella tavalla isyyden kuvausta. Hänen aineistonsa osoittaa kuinka muistelukerronnassa on olemassa kaksi toisilleen vastakkaista muistikuvaa 1900-luvun alkupuolen isyydestä. Toinen kuvaa isän pelottavana kurinpitäjänä ja auktoriteettina ja toinen taas rakentaa kuvan lapsiaan hoitavasta ja huolehtivasta isästä. Edellistä kuvaa voidaan pitää kulttuurisesti jaettuna tarinana agraarisen Suomen perheenpäästä. Jälkimmäinen on harvinaisempi. Menneisyyden isyys on siis kilpailevien ajattelutapojen ja ihanteiden kenttä. Isyys on rakentunut osana yhteiskunnan ideologioita ja kehityskulkuja. On erotettava toisistaan menneisyyden ihanteet ja toisaalta menneisyyden moninaisuus. (Aalto 2010, 15-16; 34-35.)

\section{HISTORIA KERTOO NYKYHETKESTÄ}

Palaan vielä lopuksi historian näkökulman ajankohtaisuuteen. Turkulaiset sukupuolihistorian tutkijat ja opettajat (Aalto ym. 2011, 47-48) muistuttivat vuonna 2011 kirjoittamassaan pamfletissa, että sukupuolentutkimuksessa ja feministisessä tutkimuksessa on syytä muistaa myös historiatietoisuus. Käsitykset nykyisestä ja tulevasta rakentuvat aina sille, mitä menneisyydestä tiedetään tai kuvitellaan tiedettävän. Tarvitaan työkaluja ilmiöiden ajallisen kerrostuneisuuden tunnistamiseen, sillä ellemme tunne näitä kerroksia, kuvittelemme nykyhetken harhaanjohtavalla tavalla ainutlaatuiseksi.

Myös sukupuoli on ajassa jatkuvasti rakentuva sosiaalinen ja kulttuurinen ilmiö. On tärkeää nähdä historian mahdollisuus katkoksien ja hävinneiden ilmiöiden menneisyytenä.

Elämme aikakautta, joka entistä kipeämmin tarvitsee historiallista tajua ja ymmärrystä. Historian tutkimus - myöskään kasvatuksen historian tutkimus - ei ole vain kertomuksia menneisyydestä. Historiantutkimus voi antaa välineitä ymmärtää ja auttaa suhteellistamaan tämän päivän keskeisiä yhteiskunnallisia ja kulttuurisia ilmiöitä.

\section{Annukka Jauhiainen}

$F T$, yliopistonlehtori

Turun yliopisto 


\section{LÄHTEET}

Ahonen, S. (1998). Historiaton sukupolvi? Historian vastaanotto ja historiallisen identiteetin rakentuminen 1990-luvun nuorison keskuudessa. Helsinki: Suomen Historiallinen Seura.

Aalto, I. (2010). Katsaus isyyden historiaan säätyyhteiskunnasta nykyaikaan. Teoksessa J. Mykkänen \& I. Aalto (toim.) Isyyden ihanteet, arki ja kokemukset. Raportti isyyden tutkimuksesta Suomessa. Nuorisotutkimusseura. Nuorisotutkimusverkoston verkkojulkaisuja 34, 15-35.

Aalto, I., Kaartinen, M., Konola, A., Lahtinen, A., LeskeläKärki M \& Tuohela, K. (2011). Ajatuksia historiasta sukupuolentutkimuksen kentällä. Naistutkimus 24(1), 44-49.

Goodman, J. \& Martin, J. (2000). Breaking boundaries: gender, politics, and the experience of education. History of Education 29(5), 383-388.

Goodman, J. \& Martin, J. (2004). Editorial: History of Education -Defining the field. History of Education 33(1), 1-10.

Jauhiainen, A. (2012). Ulossulkemisen muodot: tapaus Kaino Oksanen. Teoksessa H. Silvennoinen \& P. Pihlaja (toim.) Rajankäyntejä. Tutkimuksia normaaliuden, erilaisuuden ja poikkeavuuden tulkinnoista ja määrittelyistä. Turun yliopiston kasvatustieteiden tiedekunnan julkaisusarja A: Tutkimuksia A:214, 189-203.

Jauhiainen, A. (2002). Työväen lasten koulutie ja nuorisokasvatuksen yhteiskunnalliset merkitykset. Kansakoulun jatko-opetuskysymys 1800-luvun lopulta 1970-Iuvulle. Turun yliopisto. Annales Universitatis Turkuensis C: 187.

Jauhiainen, A. (2014). Tapaus Kaino Oksanen ja sukupuolihistorian merkitys. Diskursiivinen valta 1900-luvun alun suomalaisessa yliopistomaailmassa. Sukupuolentutkimus 27(1), 31-43.

Jokinen, A., Ahlbäck, A. \& Kinnarinen, K. (2012). Näkymätön sukupuoli näkyväksi. Teoksessa Jokinen, A. (toim.) Mieskysymys. Miesliike, -työ, -tutkimus ja tasa-arvospolitiikka. Tampere: Tampere University Press, 171-185.
Kujala, J. (2008). Miesopettaja itsenäisyyden ajan Suomessa elokuvan ja omaelämäkerran mukaan. Oulu: Oulun yliopisto.

Liljeström, M. (2004). Kokemukset ja kontekstit historiantutkimuksessa. Teoksessa M. Liljeström (toim.) Feministinen tietäminen. Keskustelua metodologiasta. Tampere; Vastapaino, 141-166.

Löfström, J., Oittinen, R. \& Rantala, J. (2011). Historiatietoisuuden hyödystä. Kasvatus \& Aika 5(3), 3-4.

Oljemark. J. (2011). Menneisyyden merkitys syrjäytymisvaarassa olevien pajanuorten tulevaisuuskuvissa. Kasvatus \& Aika 5(3), 54-67.

Ollila, A. (2001). Naishistoria ja sukupuolijärjestelmä. Teoksessa Immonen, K. \& Leskelä-Kärki, M. (toim.) Kulttuurihistoria. Johdatus tutkimukseen. Helsinki: Suomalaisen Kirjallisuuden Seura, 75-90.

Rahikainen M. (2008). Kenen historiaa kasvatuksen ja koulutuksen historiassa on kirjoitettu? KasHisNet. http://www.enorssi.fi/enorssi-verkosto/virmo/ virmo-1/kashisnet/kasvatuksen-historian-tutkimus/ kenen-kasvatuksen-historiaa (haettu 8.8.2016).

Torsti, P. (2012). Suomalaiset ja historia. Helsinki: Gaudeamus.

Vehkalahti, K., Tuomaala-Sarpong, S. \& Hakosalo, H. (2014). Sukupuolihistorian näkökulmia kasvatushistoriaan. Pääkirjoitus. Kasvatus \& Aika 8(1), 3-7.

Vuorikoski, M. \& Ojala, H. (2006). Sukupuoli aikuiskasvatuksen tutkimuskohteeksi. Aikuiskasvatus 26(4). 316-322.

Watts, R. (2003). Science and women in the history of education: expanding the archive. History of Education 32(2), 189-199.

Watts, R. (2005). Gendering the story: change in the history of education. History of Education 34(3), 225-241. 